\title{
Scientometrics analysis of recent trends in Global Corona virus Research
}

Krishnamurthy M ( $\triangle$ mkrishnamurthy@hotmail.com)

DRTC,Indian Statistical Institute https://orcid.org/0000-0002-8578-1533

Bhalachandra S Deshpande

Bangalore North University

Sajana C

ISRO

\section{Research Article}

Keywords: Coronavirus, Covid-19, Pandemic, Epidemiology, Scientometric

Posted Date: August 19th, 2020

DOI: https://doi.org/10.21203/rs.3.rs-43995/v1

License: (c) (i) This work is licensed under a Creative Commons Attribution 4.0 International License. Read Full License 


\section{Abstract}

Background: The worldwide pandemic COVID-19 has produced a wealth of research more rapidly after the outbreak. In just a couple of months, there is a rise in several studies on Coronavirus, adding up to the scholarly literature.

Method: The current study attempts to Scientometric analyze very recent literature on Coronaviruses just before and after the outbreak. Besides, the objective of this exploration was to assess the global research progress on Coronavirus in recent times. The current research is an analytical descriptive study using Scientometrics. The study sample includes research papers about the Coronavirus indexed in Web of Science (WoS) database from January 1, 2019 to May 14, 2020. The records with topic search (includes Title, Abstract, Keywords and Keywords Plus) "coronavirus" were extracted. These data were analyzed by MS Excel and the visualizations were created using Tableau

Result: The results showed that 2551 scientific literature about the Coronavirus was indexed in WoS. A considerable number of these articles were published in journals such as the Journal of Medical Virology, Viruses, Nature, and Lancet. Authors from China, USA and Italy were the most prolific authors. About $47.51 \%$ articles received total of 11435 citations with an average of 9 citations, which indicates that nearly half articles were cited in another publication. The highest and lowest citations for these articles were 737 and 1, respectively.

Conclusion: These results show a high rate of research on Coronavirus.

\section{Introduction}

Even though the research in various Microbiological fields is vibrant, of late the Coronavirus

and its research have gained extreme attention among the general public. It has brought about a sudden change in our regular lifestyle which was unimaginable earlier. Coronavirus disease (COVID-19) is a previously undiscovered coronavirus which causes the infectious disease. Whenever an infected patient coughs or sneezes, the COVID-19 virus spreads mainly through particles of saliva or discharge from the nose. The majority of the people infected with COVID-19 will have mild to moderate respiratory problems [1]. The impact of the Coronavirus has created a sense of panic and indeed has proved to be fatal to citizens of various countries. Global nations are continuously fighting to withstand and eradicate this catastrophic virus to save the lives of many.

Currently, vaccines or treatments are not available for COVID-19. But, several studies are being conducted for inventing prospective treatments for the Coronavirus disease. The evaluation of such scholarly output becomes absolutely necessary for understanding the on-going and latest research trend and progress. The present study uses the scientometrics techniques to understand the advancement and influence of research in Coronaviruses.

\section{Coronaviruses: An Overview}

A coronavirus is a common virus that causes nose, sinus, or upper throat infection [2]. In early 2020, the World Health Organization (WHO) identified SARS-CoV-2 as a new type of Coronavirus, after an epidemic in China in December 2019. COVID-19 is an infection caused by SARS-CoV-2, which healthcare professionals call an infection in the respiratory system. It may affect one's upper respiratory system (sinus, nose, throat) or lower respiratory system (windpipe, lungs). It tends to spread the same manner like other coronaviruses, primarily via contact from human to human. Infections vary from mild to severe.

SARS-CoV-2 is among seven categories of influenza virus, including those causing serious diseases such as respiratory syndrome in the Middle East (MERS) and Sudden Acute Respiratory Syndrome (SARS). Other coronaviruses cause much of the common cold throughout the year that impact individuals, but are not a serious threat to healthy people. The virus can cause pneumonia, shortness of breath, septicaemia and mortality. It continues to spread mostly, when a patient coughs or sneezes. They can discharge particles to a distance of 6 feet. The virus can get through one's body if they breathe them in or swallow. Infected people having no symptoms can still spread the disease. Human beings could also get the infection by contacting an infected surface over which the virus is there, then touching their face. Most of the viruses can live on a surface for several hours.

\section{Related Literature}

Pouris, A., \& Pouris, A. (2010) [3] identified the state of South Africa's HIV / AIDS related study with regard to the rest of the world utilizing analytic scientometrics to notify action plans. South Africa was identified as producing an increasing number of HIV/AIDS-related publications, making it one of the most prolific fields in the country. While the USA was recognized as the leading producer of HIV/AIDS research. Fricke, R., Uibel, S., Klingelhoefer, D., \& Groneberg, D. A. (2013) [4] study revealed an increasing and broad research attention in Influenza. However, the study showed citation-based scientific quality proclamation should be considered significant because of deviation by co-authorship and self-citation. Scutaru, C., Quarcoo, D., Sakr, M. et al. (2010) [5] study constituted first ever comprehensive bibliometric analysis of European studies on allergies. The data showed a marked hike in research ouput, combined with novel tools such as density-equalizing mapping, internationally established databases such as the PubMed or Web of Science should be assessed in long run. Luchs, Adriana (2012) [6] between 2009 and 2011 analyzed the Brazilian scientific production in the influenza field A (H1N1). 95 percent of Brazilian output emerged in the Southern and Southeast areas of the country. 
Yao, Q., Chen, K., Yao, L. et al. (2014) [7] showed that health systems research (HSR) has increased rapidly from over 20 years. Study in this area has focused primarily on general populace, environmental and occupational health (21.46\%), public healthcare sciences and services (20.29\%), general and internal medicine (13.14\%). Batcha, M. S. (2018) [8] derived data from the Web of Science to provide a qualitative and quantitative comparison between worldwide Swine Flu research and 25 year Indian publications (1993-2017). Where India's research output on Swine Flu research was widely scattered across various journals and this tendency seems to be one of the factors of its limited citation impact. Bhattacharya, S., \& Singh, S. (2020) [9] tried to identify which articles are the most influential, the key body of knowledge and the major research topics in COVID-19. Study observed that all of the top co-cited papers were published in high impact factor journals. It was also found that many studies were driven by epidemiology and clinical characteristics of the disease. The trends observed in measures like lockdown, social distancing and quarantine at global and country level showed the societal increasing concern with these aspects. Haghani, M., Bliemer, M. C., Goerlandt, F., \& Li, J. (2020) [10] conducted analysis that identifies a variety of potential problems induced by this world health crisis that has attracted only narrow research attention but may warrant more interest. It included issues such as internet security, economic security, and the protection of supply chains. Zhang, L., Zhao, W. J., Sun, B. B., Huang, Y., \& Glänzel, W. (2020) [11] discovered that academic community have often acted immediately to crises of global health with a substantial increase in the papers directly following the WHO's statement of pandemic. Study in the areas of virology, contagious diseases and immunology has been the most productive, and have found two specific characteristics in world - wide science that differentiate studies in America and Europe that concentrates mostly on population health from that in Japan and China, with stronger focus respectively on biomedical research and clinical pharmacy. Di Girolamo, N., \& Reynders, R. M. (2020) [12] evaluated the characteristics of papers published during the COVID-19 pandemic's first 3 months and compared them with publications during the H1N1 swine influenza pandemic (2009). Their study found that common publications have been on public health research (59.1\%), silico research (31.7\%) and in vitro research (4.5\%). Among the human clinical research, the large majority were observation research and series of cases, followed by single clinical studies and one randomised controlled trial. Also, there have been 223 papers published about the H1N1 pandemic in a similar time period in 2009.

Bras, P. L. [et al.] (2020) [13] developed a new theme-based visualization method which is automated, merging innovative data modeling, information mapping and predictive analytics, giving top-down as well as bottom-up search user interface for faster topic discovery and online information. The findings revealed interesting information regarding many efforts on topics like social distancing; cross-domain initiatives; evolving research on healthcare topics. Batooli, Z., \& Sayyah, M. (2020) [14] evaluated the amount of attention given to 1910 articles indexed in Dimensions to COVID-19 scholarly output in social media over a four month period. These results of the study indicated a great amount of attention among the social media scientists and users to the publications outlined on COVID-19. The study also indicated a significant positive correlation between citations and the Altmetrics measures and a relatively high demand \& supply for information in the COVID-19 field.

\section{Research Questions}

- What are the recent trends of scholarly publications on Coronavirus one year before and few months after spreading of the pandemic?

- Which are the priority research areas among top countries in Coronavirus research?

- Who have published quality research papers in Coronavirus research?

- What is the extent of collaboration among scientists of top countries?

- Which are the highly cited articles and most ranked journal?

\section{Methods}

\subsection{Data Collection}

Data for the study was retrieved from the Web of Science (WoS) database maintained by Clarivate Analytics. "Coronavirus" was searched in the Topic field to retrieve the overall data required for the study. The Topic search in Web of Science includes results from Title, Abstract, Keywords and Keywords Plus fields. The time period of the study covers the data from January 1, 2019 to May 14, 2020. The timeframe considered recent research published before and after the spread of Pandemic in December 2019.

\section{Data Analysis}

Papers retrieved from the WoS were evaluated by date of the publication, countries, title, author and organization. Results of the study were evaluated and converted to graphs in MS Excel.. The overall amount of citations and the average citation for every paper were assessed for all articles published that referred to Coronavirus. The amount of literature could be used as an indicator of the amount of output in this regard. Analysis of citations is being used as a measure for both the publications impact on the research community and for the quality of study. Author Collaboration related data visualization was created using Tableau [15].

Finally, quality of research papers and priority of research in Coronavirus among countries was explored. Other, analysis of data revealed highly cited articles, prominent funding agencies, major disciplines within which Coronavirus research is being conducted and the prolific journal that has published majority of Coronavirus research papers. 


\section{Results}

\section{Amount of published items}

The query in the Web of Science (WoS) database resulted in 2551 publications with a reference to Coronavirus. In the study time frame, a rapid increase of publications in this subject area can be observed (Fig. 2); especially a remarkable increase in Coronavirus related research output in WoS can be noted in the current year i.e. 2020. Almost more than half of the publications (62 percent) were published in the current year. All the highly cited publications were found in 2020.

\subsection{Authorship Trends in top Countries}

It is evident from the Figure 3, that about $89 \%$ were collaborative research either by two authors or more than two authors. Only $11 \%$ of contributions were by single authors. China followed by USA and all other countries with top publication output showed highest number of collaborative authorship with more than three authored papers.

Figure 4, shows that the degree of collaboration between the top productive countries ranges between 0.83 and 0.95 . This indicates the high extent of research collaboration among the countries. While the Collaborative Index $(\mathrm{Cl})$ ranges between 3.15 and 3.60 . This indicates that there is at least average of 3 authors per joint article.

Table 1 Authorship collaboration as in top Countries

\begin{tabular}{|lllllllll|}
\hline Countries & No. of Records & 1 Author & 2 Authors & 3 & $>3$ Authors & DC & Cl & CC \\
\hline China & 747 & 704 & 68 & 78 & 495 & 0.86 & 3.29 & 0.61 \\
\hline USA & 391 & 39 & 63 & 37 & 251 & 0.90 & 3.28 & 0.63 \\
\hline Italy & 119 & 15 & 14 & 16 & 72 & 0.87 & 3.24 & 0.61 \\
\hline South Korea & 95 & 11 & 8 & 10 & 65 & 0.88 & 3.37 & 0.63 \\
\hline England & 90 & 15 & 13 & 5 & 56 & 0.83 & 3.15 & 0.58 \\
\hline Saudi Arabia & 61 & 5 & 7 & 10 & 39 & 0.92 & 3.36 & 0.65 \\
\hline Germany & 59 & 3 & 4 & 6 & 45 & 0.95 & 3.60 & 0.69 \\
\hline India & 57 & 8 & 5 & 5 & 39 & 0.86 & 3.32 & 0.62 \\
\hline France & 52 & 9 & 3 & 6 & 34 & 0.83 & 3.25 & 0.60 \\
\hline Canada & 48 & 4 & 5 & 2 & 37 & 0.92 & 3.50 & 0.66 \\
\hline Japan & 48 & 5 & 6 & 4 & 33 & 0.90 & 3.35 & 0.63 \\
\hline Iran & 40 & 6 & 4 & 6 & 24 & 0.85 & 3.20 & 0.60 \\
\hline Switzerland & 39 & 6 & 1 & 4 & 28 & 0.85 & 3.38 & 0.62 \\
\hline Netherlands & 37 & 3 & 1 & 3 & 30 & 0.97 & 3.68 & 0.70 \\
\hline Brazil & 34 & 4 & 3 & 26 & 0.91 & 3.56 & 0.67 \\
\hline
\end{tabular}

\subsection{Relative Quality Index (RQI)}

The Relative Quality Index (RQI) for various top countries relates to the frequency of high quality papers for a given country.

Table 2 Relative Quality Index (RQI) 


\begin{tabular}{|llllllll|}
\hline Country & TNP & TNC & CPP & NHQ & TNP\% & NHQ\% & RQI \\
\hline China & 747 & 7229 & 9.68 & 3 & 29.28 & 1.91 & 0.07 \\
\hline USA & 391 & 1423 & 3.64 & 18 & 15.33 & 11.46 & 0.75 \\
\hline Italy & 119 & 210 & 1.76 & 7 & 4.66 & 4.46 & 0.96 \\
\hline South Korea & 95 & 182 & 1.92 & 7 & 3.72 & 4.46 & 1.20 \\
\hline England & 90 & 290 & 3.22 & 8 & 3.53 & 5.10 & 1.44 \\
\hline Saudi Arabia & 61 & 164 & 2.69 & 8 & 2.39 & 5.10 & 2.13 \\
\hline Germany & 59 & 258 & 4.37 & 3 & 2.31 & 1.91 & 0.83 \\
\hline India & 57 & 51 & 0.89 & 7 & 2.23 & 4.46 & 2.00 \\
\hline France & 52 & 99 & 1.90 & 4 & 2.04 & 2.55 & 1.25 \\
\hline Canada & 48 & 229 & 4.77 & 3 & 1.88 & 1.91 & 1.02 \\
\hline Japan & 48 & 146 & 3.04 & 8 & 1.88 & 5.10 & 2.71 \\
\hline Iran & 40 & 37 & 0.93 & 5 & 1.57 & 3.18 & 2.03 \\
\hline Switzerland & 39 & 102 & 2.62 & 4 & 1.53 & 2.55 & 1.67 \\
\hline Netherlands & 37 & 138 & 3.73 & 5 & 1.45 & 3.18 & 2.20 \\
\hline Brazil & 34 & 11 & 0.32 & 6 & 1.33 & 3.82 & 2.87 \\
\hline Others & 634 & 866 & 1.37 & 61 & 24.85 & 38.85 & 1.56 \\
\hline Total & $\mathbf{2 5 5 1}$ & $\mathbf{1 1 4 3 5}$ & $\mathbf{4 . 4 8}$ & $\mathbf{1 5 7}$ & $\mathbf{1 0 0 . 0 0}$ & $\mathbf{1 0 0 . 0 0}$ & $\mathbf{1 . 0 0}$ \\
\hline
\end{tabular}

TNP - Total Number of Papers, TNC - Total Number of Citations, CPP - Citation Per Paper, NHQ - Number of High Quality Papers, RQI - Relative Quality Index

The top countries along with their total number of publications, citation per paper (CPP), total citations, number of high quality papers and relative quality index are indicated in Table 2. The average value of CPP is 2.93. The value of CPP is highest for the China. Other countries having higher than average value for CPP are USA, England, Germany, Canada, Japan and Netherlands. Table 2 also indicates that since the value of the RQI is more than 1 the countries namely South Korea, England, Saudi Arabia, Germany, India, France, Canada, Japan, Iran, Switzerland, Netherlands and Brazil have higher than average frequency of high quality papers. For the other countries, the incidence of high quality papers is less than average. The value of the RQI is highest in case of Brazil (2.87) in comparison to the other countries, which implies that it has more quality research output than other countries (Fig. 5).

\subsection{Highly Cited articles}

Table 3 Highly Cited articles 


\begin{tabular}{|c|c|c|c|}
\hline Authors & Title & Journal & Citations \\
\hline $\begin{array}{l}\text { Huang, } \\
\text { Chaolin et al. }\end{array}$ & Clinical features of patients infected with 2019 novel coronavirus in Wuhan, China & Lancet & 737 \\
\hline Zhu, Na et al. & A Novel Coronavirus from Patients with Pneumonia in China, 2019 & $\begin{array}{l}\text { New England } \\
\text { Journal of } \\
\text { Medicine }\end{array}$ & 436 \\
\hline $\begin{array}{l}\text { Chen, Nanshan } \\
\text { et al. }\end{array}$ & $\begin{array}{l}\text { Epidemiological and clinical characteristics of } 99 \text { cases of } 2019 \text { novel coronavirus } \\
\text { pneumonia in Wuhan, China: a descriptive study }\end{array}$ & Lancet & 424 \\
\hline $\begin{array}{l}\text { Wang, Dawei } \\
\text { et al. }\end{array}$ & $\begin{array}{l}\text { Clinical Characteristics of } 138 \text { Hospitalized Patients With } 2019 \text { Novel Coronavirus-Infected } \\
\text { Pneumonia in Wuhan, China }\end{array}$ & $\begin{array}{l}\text { Journal of The } \\
\text { American Medical } \\
\text { Association }\end{array}$ & 389 \\
\hline $\begin{array}{l}\text { Zhou, Peng et } \\
\text { al. }\end{array}$ & A pneumonia outbreak associated with a new coronavirus of probable bat origin & Nature & 308 \\
\hline Li, Qun et al. & Early Transmission Dynamics in Wuhan, China, of Novel Coronavirus-Infected Pneumonia & $\begin{array}{l}\text { New England } \\
\text { Journal of } \\
\text { Medicine }\end{array}$ & 284 \\
\hline $\begin{array}{l}\text { Chan, Jasper } \\
\text { Fuk-Woo et al. }\end{array}$ & $\begin{array}{l}\text { A familial cluster of pneumonia associated with the } 2019 \text { novel coronavirus indicating } \\
\text { person-to-person transmission: a study of a family cluster }\end{array}$ & Lancet & 272 \\
\hline $\begin{array}{l}\text { Lu, Roujian et } \\
\text { al. }\end{array}$ & $\begin{array}{l}\text { Genomic characterisation and epidemiology of } 2019 \text { novel Coronavirus: implications for } \\
\text { virus origins and receptor binding }\end{array}$ & Lancet & 236 \\
\hline $\begin{array}{l}\text { Holshue, } \\
\text { Michelle L. et } \\
\text { al. }\end{array}$ & First Case of 2019 Novel Coronavirus in the United States & $\begin{array}{l}\text { New England } \\
\text { Journal of } \\
\text { Medicine }\end{array}$ & 182 \\
\hline $\begin{array}{l}\text { Wu, Zunyou; } \\
\text { McGoogan, } \\
\text { Jennifer M. }\end{array}$ & $\begin{array}{l}\text { Characteristics of and Important Lessons From the Coronavirus Disease } 2019 \text { (COVID-19) } \\
\text { Outbreak in China Summary of a Report of } 72314 \text { Cases From the Chinese Center for } \\
\text { Disease Control and Prevention }\end{array}$ & $\begin{array}{l}\text { Journal of The } \\
\text { American Medical } \\
\text { Association }\end{array}$ & 163 \\
\hline
\end{tabular}

The paper by Huang, Chaolin [et al.] on Clinical features of patients infected with 2019 novel coronavirus in Wuhan, China was found to be the most highly cited publication with 737 citations as illustrated in Table 3. Surprisingly, all the top cited articles include collaboration of authors. Majority of top cited papers were from Lancet journal securing 1669 citations.

7.4.Top Sub-fields Vs. No. of records

Table 4 Top Sub-fields Vs. No. of records 


\begin{tabular}{|llll|}
\hline SI. No & Subfield & Subfield Code & No. of Records \\
\hline 1. & Coronavirus & CNV & 431 \\
\hline 2. & COVID-19 & COV & 493 \\
\hline 3. & Severe acute respiratory syndrome corona virus 2 (SARS-CoV-2) & SAR & 245 \\
\hline 4. & 2019-nCoV & NCV & 79 \\
\hline 5. & Pandemic & PND & 72 \\
\hline 6. & Epidemiology & EPI & 61 \\
\hline 7. & Infection & INF & 42 \\
\hline 8. & SARS & SRS & 36 \\
\hline 9. & SARS coronavirus (SARS-CoV) & SCV & 34 \\
\hline 10. & Novel coronavirus (2019-nCoV) & NLC & 34 \\
\hline 11. & Outbreak & OUB & 34 \\
\hline 12. & Influenza & INZ & 33 \\
\hline 13. & Infectious bronchitis virus & IBR & 33 \\
\hline 14. & Porcine epidemic diarrhea virus (PEDV) & PED & 24 \\
\hline 15. & Vaccine & VAC & 23 \\
\hline
\end{tabular}

COVID-19 (COV), Coronavirus (CNV), Severe acute respiratory syndrome corona virus 2 (SAR), 2019-nCoV (NCV), Pandemic (PND), Epidemiology (EPI), Infection (INF), SARS (SRS), SARS coronavirus (SCV), Novel coronavirus (NLC), Outbreak (OUB), Influenza (INZ), Infectious bronchitis virus (IBR), Porcine epidemic diarrhea virus (PED), Vaccine (VAC).

About $19.33 \%$ of publications on subfield 'COVID-19' have resulted in highest number (493) of publications. It is followed by research in 'Coronavirus' 431 (16.90\%), 'Severe acute respiratory syndrome corona virus 2' 245 (9.60\%), '2019-nCoV' 79 (310) and 'Pandemic' 72 (2.82\%). The output in other top sub-fields were in the range between $2.39 \%$ and $0.90 \%$ contributions (Table 4 ).

\subsection{Research Priority Index (RPI) of top countries}

The mere assessment of quantum of publications perhaps may not be an effective method to judge the quantity of output in respective sub-fields of a subject field. Hence, the technique Research Priority Index (RPI) is employed in the present study to measure the Coronavirus research output by various top countries in the top sub-fields, enabling cross-national comparison is presented in Table 5.

Table 5 Research Priority Index (RPI) of top countries

\begin{tabular}{|llllllllllllllll|}
\hline Countries & CNV & COV & SAR & NCV & PND & EPI & INF & SRS & SCV & NLC & OUB & INZ & IBR & PED & VAC \\
\hline China & 78.2 & 108.2 & 246.7 & 147.2 & 54.4 & 123.3 & 105.7 & 96.9 & 105.7 & 188.6 & 85.8 & 33.6 & 164.4 & 164.4 & 77.1 \\
\hline USA & 122.5 & 85.4 & 0.0 & 32.9 & 165.9 & 22.7 & 58.3 & 72.8 & 174.8 & 95.9 & 70.9 & 222.4 & 90.6 & 135.9 & 127.4 \\
\hline Italy & 108.8 & 117.2 & 0.0 & 64.5 & 50.8 & 111.0 & 190.3 & 178.4 & 142.7 & 0.0 & 86.9 & 45.4 & 0.0 & 0.0 & 62.4 \\
\hline $\begin{array}{l}\text { South } \\
\text { Korea }\end{array}$ & 87.9 & 117.8 & 0.0 & 179.0 & 75.3 & 0.0 & 105.7 & 79.3 & 0.0 & 0.0 & 482.6 & 0.0 & 0.0 & 0.0 & 0.0 \\
\hline England & 136.1 & 93.0 & 0.0 & 76.7 & 80.6 & 88.1 & 75.5 & 169.9 & 0.0 & 0.0 & 68.9 & 72.1 & 58.7 & 0.0 & 99.1 \\
\hline Germany & 164.9 & 101.5 & 0.0 & 73.2 & 0.0 & 252.3 & 0.0 & 0.0 & 0.0 & 0.0 & 0.0 & 0.0 & 0.0 & 0.0 & 0.0 \\
\hline $\begin{array}{l}\text { Saudi } \\
\text { Arabia }\end{array}$ & 57.3 & 48.5 & 0.0 & 70.1 & 0.0 & 362.0 & 413.7 & 155.1 & 0.0 & 0.0 & 377.7 & 789.7 & 0.0 & 0.0 & 542.9 \\
\hline India & 98.2 & 112.8 & 0.0 & 137.1 & 180.1 & 59.0 & 0.0 & 151.8 & 0.0 & 0.0 & 0.0 & 0.0 & 78.7 & 0.0 & 132.8 \\
\hline Japan & 121.5 & 58.7 & 0.0 & 0.0 & 0.0 & 584.2 & 250.4 & 0.0 & 0.0 & 0.0 & 228.6 & 0.0 & 194.7 & 0.0 & 328.6 \\
\hline France & 98.9 & 83.7 & 0.0 & 107.4 & 508.0 & 0.0 & 0.0 & 0.0 & 0.0 & 0.0 & 0.0 & 151.4 & 0.0 & 0.0 & 0.0 \\
\hline
\end{tabular}


By comparing the output of research between the top countries (Table 5), it was perceived that the highest priority (RPI $>400$ ) of Coronavirus research have been in the following sub-fields namely 'Pandemic' (PND), 'Epidemiology' (EPI), 'Infection' (INF), 'Outbreak' (OUB), 'Influenza' (INZ), 'Vaccine' (VAC). Moreover, among top subfields Italy has given most priority towards research on COVID-19 (COV), Germany on Coronavirus (CNV), China alone on Severe acute respiratory syndrome corona virus 2 (SAR), South Korea on 2019-nCoV (NCV), France on Pandemic. While most prioritized research (RPI >100) on Vaccines (VAC) was found to be conducted by Saudi Arabia followed by Japan, India and USA.

\subsection{Language-wise Distribution}

The English is largely considered to be the lingua franca of the scientific community. The study by Weijen (2012) indicated that researchers publishing in English tend to publish most in fields related to the 'harder' Sciences, such as Physics, Engineering and Materials Science than 'softer' Sciences like health and Social Sciences. The results presented in fig. 6 also indicate that English with 2507 (98.28\%) papers is the most preferred language of scholarly communication. It is followed by a few publications in languages like German, Hungarian, Spanish and French.

\subsection{Funding agencies}

The Table 6 indicates that National Natural Science Foundation of China was found to be provided the highest funds for Coronavirus research with 251 (9.84\%) papers. The next five highest number of research grants was provided by National Institutes of Health (NIH) United States, National Key Research and Development Program of China, National Institute of Allergy and Infectious Diseases (NIAID) United States and National Science and Technology Major Project, China. Other national institutes that have funded the Coronavirus research include Japan, Canada, Korea, Brazil, European Union, Saudi Arabia and Germany. Moreover, the World health Organization has also been a key funding agency in supporting research on Coronavirus.

Table 6 Funding agencies

\begin{tabular}{|lll|}
\hline Funding Agency & Country & No. of Records \\
\hline National Natural Science Foundation of China & China & 251 \\
\hline National Institutes of Health (NIH) United States & United States & 165 \\
\hline National Key Research and Development Program of China & China & 67 \\
\hline National Institute of Allergy and Infectious Diseases (NIAID) & United States & 66 \\
\hline National Science and Technology Major Project China & China & 28 \\
\hline Japan Agency for Medical Research and Development (AMED) & Japan & 17 \\
\hline Canadian Institutes of Health Research (CIHR) & Canada & 16 \\
\hline National Research Foundation of Korea & Korea & 16 \\
\hline Fundacao de Amparo a Pesquisa do Estado de Sao Paulo & Brazil & 14 \\
\hline National Institute of General Medical Sciences & United States & 14 \\
\hline Hong Kong Health and Medical Research Fund & China & 13 \\
\hline European Commission & European Union & 13 \\
\hline Deanship of Scientific Research at King Faisal University & Saudi Arabia & 12 \\
\hline World Health Organization & - & 10 \\
\hline Deutsche Forschungsgemeinschaft German Research Foundation (DFG) & Germany & 10 \\
\hline
\end{tabular}

\subsection{Major Research Areas}

About $11.96 \%$ of publications in Virology' have resulted in highest number (305) of publications. It is followed by research in General \& Internal Medicine, Infectious Diseases, Science \& Technology - Other Topics, Biochemistry \& Molecular Biology. The outputs in other top sub-fields were in the range between $5.53 \%$ and $2.94 \%$ contributions (Table 7 ).

Table 7 Major Research Areas 


\begin{tabular}{|ll|}
\hline Major Research Areas & No. of Records \\
\hline Virology & 305 \\
\hline General \& Internal Medicine & 274 \\
\hline Infectious Diseases & 174 \\
\hline Science \& Technology - Other Topics & 154 \\
\hline Biochemistry \& Molecular Biology & 151 \\
\hline Immunology & 141 \\
\hline Veterinary Sciences & 121 \\
\hline Public, Environmental \& Occupational Health & 118 \\
\hline Microbiology & 88 \\
\hline Radiology, Nuclear Medicine \& Medical Imaging & 75 \\
\hline
\end{tabular}

\subsection{Journal-wise distribution of publications}

The Table 8 indicates that Journal of Medical Virology was found to be published the highest articles on Coronavirus research with 98 (3.84\%) papers. The next four highest numbers of publications were from journals- Viruses-Basel, Nature, Journal of Virology and British Medical Journal. Also, it can be observed that even though the high impact factor and cited journals like Lancet, Nature and British Medical journal appeared in the top in terms of publications on Coronavirus but highest publications were from lower impact factor journals mentioned above.

Table 8 Journal-wise distribution of publications

\begin{tabular}{|c|c|c|c|c|}
\hline Journals & TNP & TNP \% & TNC & Impact Factor \\
\hline Journal of Medical Virology & 98 & 3.84 & 578 & 2.049 \\
\hline Viruses-Basel & 77 & 3.02 & 262 & 3.811 \\
\hline Nature & 51 & 2.00 & 467 & 43.07 \\
\hline Journal of Virology & 45 & 1.76 & 180 & 4.324 \\
\hline British Medical Journal & 42 & 1.65 & 102 & 27.604 \\
\hline Eurosurveillance & 42 & 1.65 & 220 & 7.400 \\
\hline Chemical \& Engineering News & 37 & 1.45 & 2 & 1.126 \\
\hline Emerging Microbes \& Infections & 34 & 1.33 & 177 & 6.212 \\
\hline Lancet & 28 & 1.10 & 2296 & 59.102 \\
\hline Head and Neck-Journal for the Sciences and Specialties of the Head and Neck & 27 & 1.06 & 7 & 2.442 \\
\hline
\end{tabular}

\section{Findings And Discussion}

This study identified that the surge in the publications was after the outbreak of the pandemic. The collaborative research has also been observed to be prevalent in intra- and inter-country researches. Where, there is at least an average of 3 authors per joint article. While, Brazil has more quality research output than other countries. The study also highlighted that the paper by Huang, Chaolin [et al.] on Clinical features of patients infected with 2019 novel coronavirus in Wuhan, China was found to be the most highly cited publication. Moreover, highest priority (RPI $>400$ ) of Coronavirus research have been in the following sub-fields namely 'Pandemic' (PND), 'Epidemiology' (EPI), 'Infection' (INF), 'Outbreak' (OUB), 'Influenza' (INZ), 'Vaccine' (VAC). Wherein, most prioritized research (RPI >100) on Vaccines (VAC) was found to be conducted by Saudi Arabia followed by Japan, India and USA. Besides, National Natural Science Foundation of China was found to be provided the highest funds for Coronavirus research and Journal of Medical Virology has published the highest articles on Coronavirus research.

For decision makers and emergency personnel confronting this global crisis, quick and timely acquisition of knowledge and statistical based scientific findings is important in notifying their policy choices to the optimum via empirical proofs. In order to more accurately direct and empower academic expertise towards more efficient approaches, it also requires a consistent review of existing insight to identify the gaps and overlooked factors. It is believed that this research will help accelerate and enable these scholarly initiatives and bring the awareness of the current research status during this global crisis to the scientific community. In addition to the usual clinical implications and scientific output analysis of the COVID- 
19 pandemic which have so far dominated research publications in this field, we would like to illustrate a specific set of findings related factors like quality, impact, priorities and status of research in Coronaviruses based on recent publications, that have not been included in the other publications of similar scope.

\section{Conclusions}

The immense rise in research papers pertaining to the COVID-19 disease outbreak, and the significant research trends pertaining to several factors relating to the virus outbreak's implications, make summarizing scientific research findings more essential now than ever before. With regard to this, the objective of the current research work was to collect, record, and illustrate the possibility and extent of the current research on Coronaviruses. Specifically, the most recent research trends were identified that can help healthcare practitioners and policy makers recognize major factors in research output.

\section{Declarations}

Competing interests: The authors declare no competing interests.

\section{References}

1. 2020. https://www.who.int/health-topics/coronavirus. Accessed 20 Jun 2020.

2. Coronavirus (COVID-19) Overview. 2020. https://www.webmd.com/lung/coronavirus. Accessed 20 June 2020.

3. Pouris, A., \& Pouris, A. Scientometrics of a pandemic: HIV/AIDS research in South Africa and the World. Scientometrics. 2010; 541-552.

4. Fricke, R., Uibel, S., Klingelhoefer, D., \& Groneberg, D. A. Influenza: a scientometric and density-equalizing analysis. BMC infectious diseases. 2013; 454.

5. Scutaru, C., Quarcoo, D., Sakr, M. et al. Density-equalizing mapping and scientometric benchmarking of European allergy research. J Occup Med Toxicol 2010. https://doi.org/10.1186/1745-6673-5-2

6. Luchs, Adriana. Profile of Brazilian scientific production on A/H1N1 pandemic influenza. Ciência \& Saúde Coletiva. 2012. https://doi.org/10.1590/S1413-81232012000600025

7. Yao, Q. et al. Scientometric trends and knowledge maps of global health systems research. Health research policy and systems. $2014 ; 26$.

8. Batcha, M. S. A Scientometric Appraisal of Global Research Output on Swine Flu with Special Reference to India During 1993-2017. International Journal of Information Dissemination and Technology. 2018; 125-130.

9. Bhattacharya, S., \& Singh, S. Visible Insights of the Invisible Pandemic: A Scientometric, Altmetric and Topic Trend Analysis. arXiv preprint. 2020. arXiv:2004.10878.

10. Haghani, M., Bliemer, M. C., Goerlandt, F., \& Li, J. The scientific literature on Coronaviruses, COVID-19 and its associated safety-related research dimensions: A scientometric analysis and scoping review. Safety Science. 2020.

11. Zhang, L., Zhao, W. J., Sun, B. B., Huang, Y., \& Glänzel, W. How scientific research reacts to international public health emergencies: a global analysis of response patterns. Scientometrics. 2020.

12. Di Girolamo, N., \& Reynders, R. M. Characteristics of scientific articles on COVID-19 published during the initial three months of the pandemic: a meta-epidemiological study. medRxiv. 2020.

13. Bras, P. L., Gharavi, A., Robb, D. A., Vidal, A. F., Padilla, S., \& Chantler, M. J. Visualising COVID-19 Research. arXiv preprint arXiv:2005.06380. 2020

14. Batooli, Z., \& Sayyah, M. Measuring social media attention of scientific research on Novel Coronavirus Disease 2019 (COVID-19): An investigation on article-level metrics data of Dimensions. 2020.

15. Tableau: Business Intelligence and Analytics Software. 2020. https://www.tableau.com/. Accessed 20 Jun 2020

16. 2020. https://twitter.com/ktdatea/status/1238340191183609856. Accessed 20 Jun 2020.

\section{Figures}




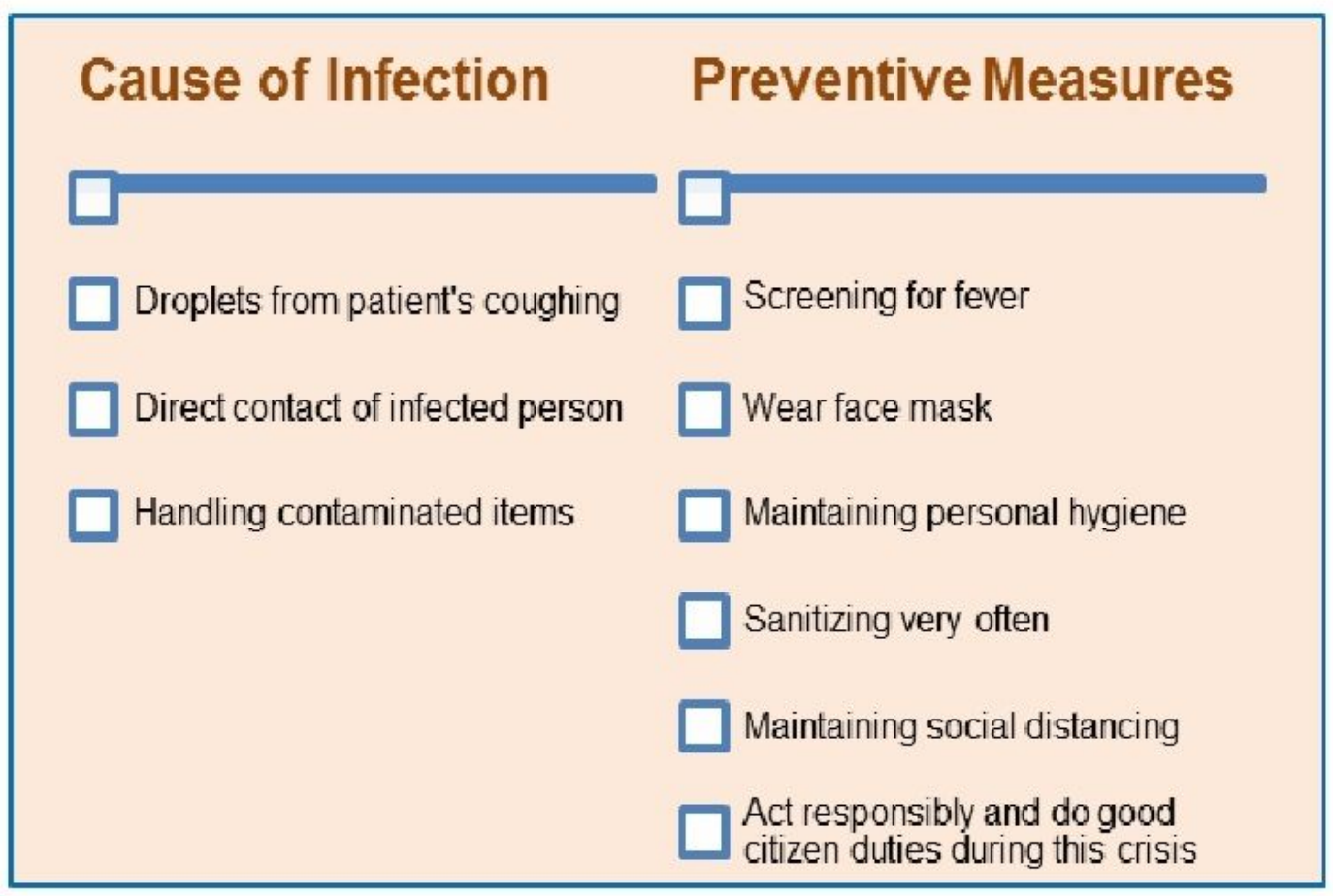

. 1 Safety measures against the spread of Coronavirus

Figure 1

Safety measures against the spread of Coronavirus

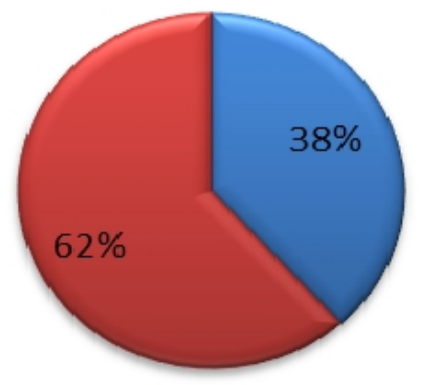

$\square 2019 \square 2020$

Fig2. Amount of published items

\section{Figure 2}

Amount of published items 


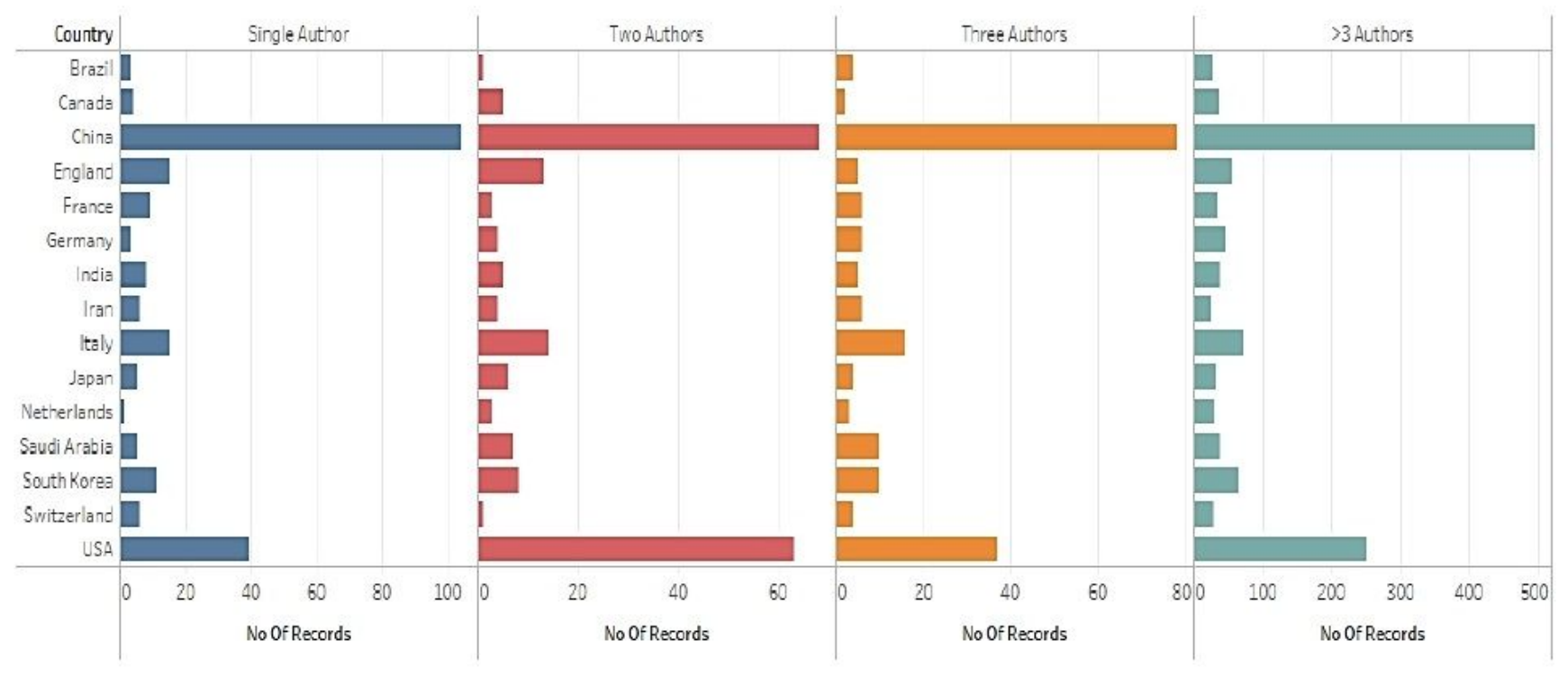

Fig. 3 Authorship Trends in top Countries

Figure 3

Authorship Trends in top Countries

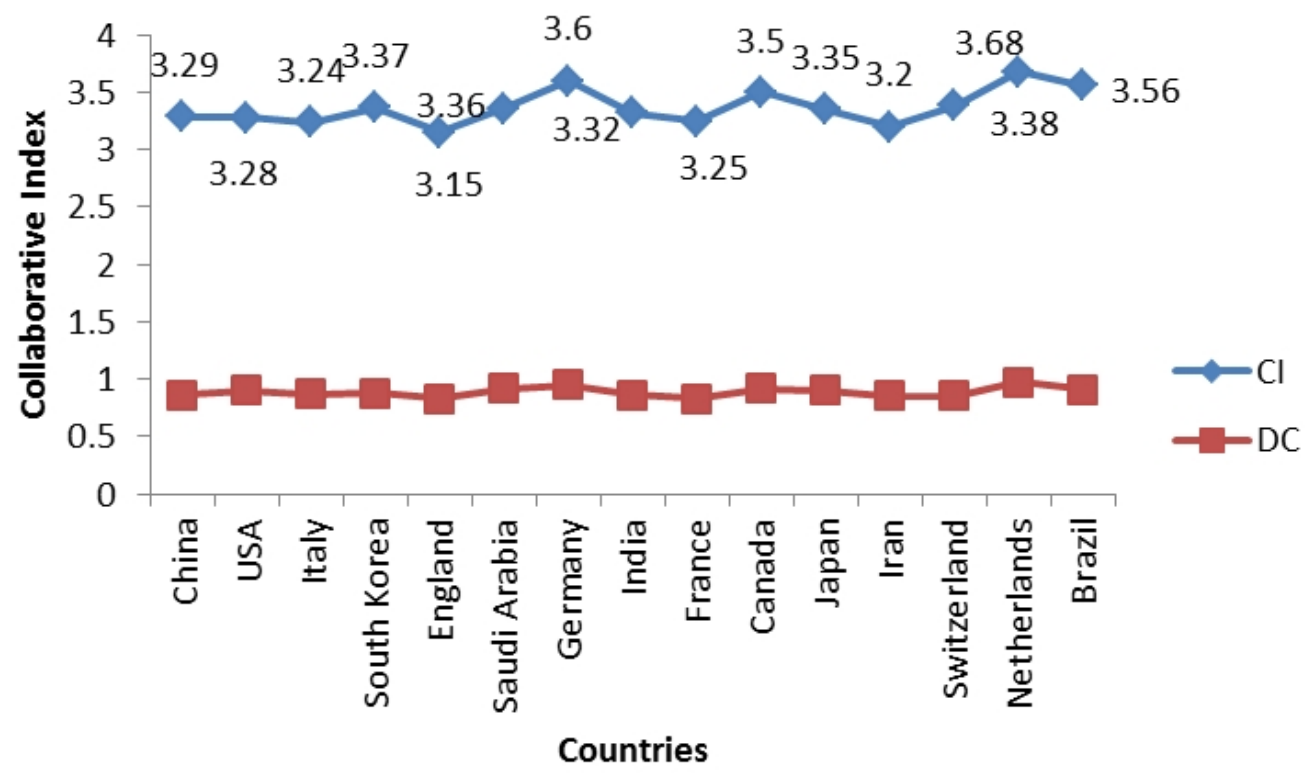

Fig. 4 Collaborative Index (Cl) 


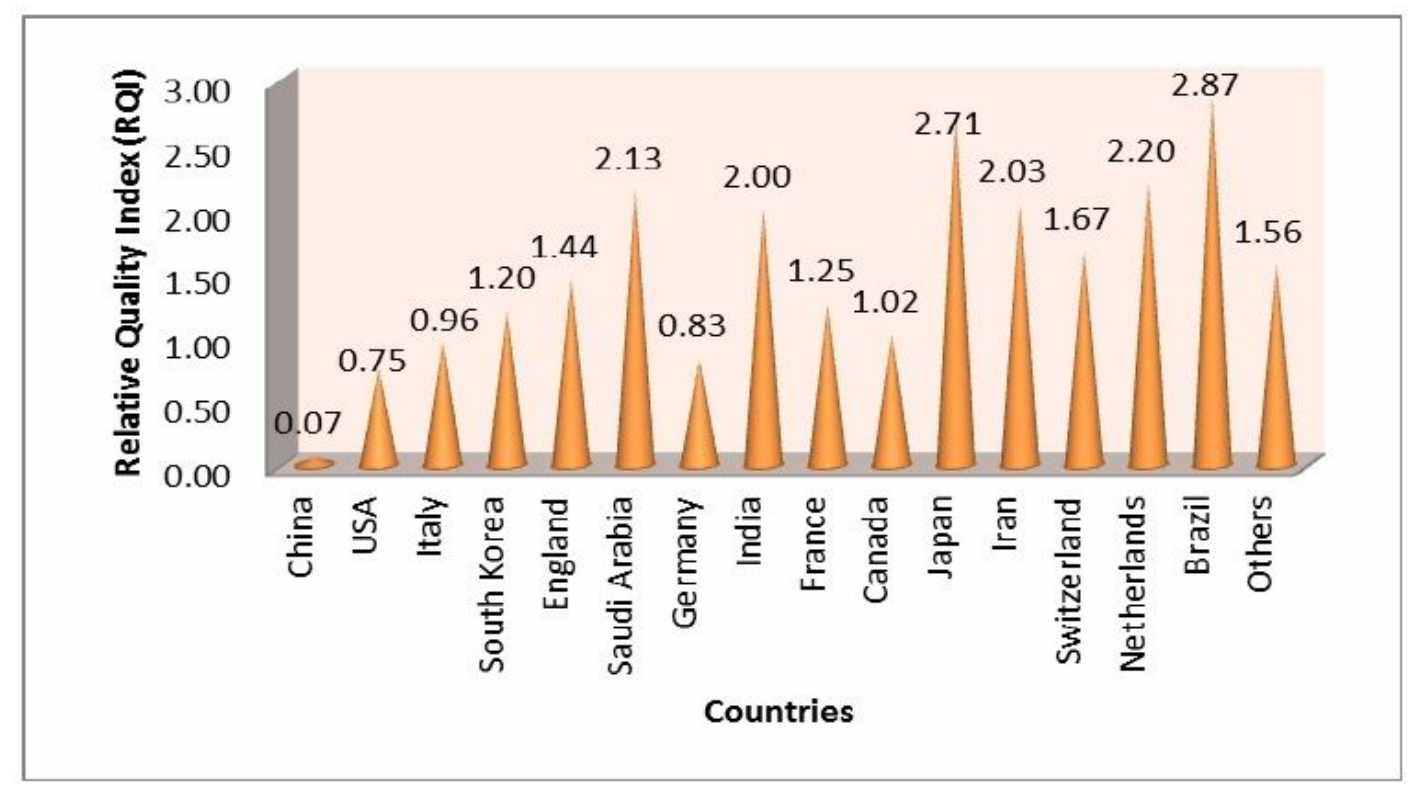

Fig. 5 Relative Quality Index (RQI)

Figure 5

Relative Quality Index (RQI)

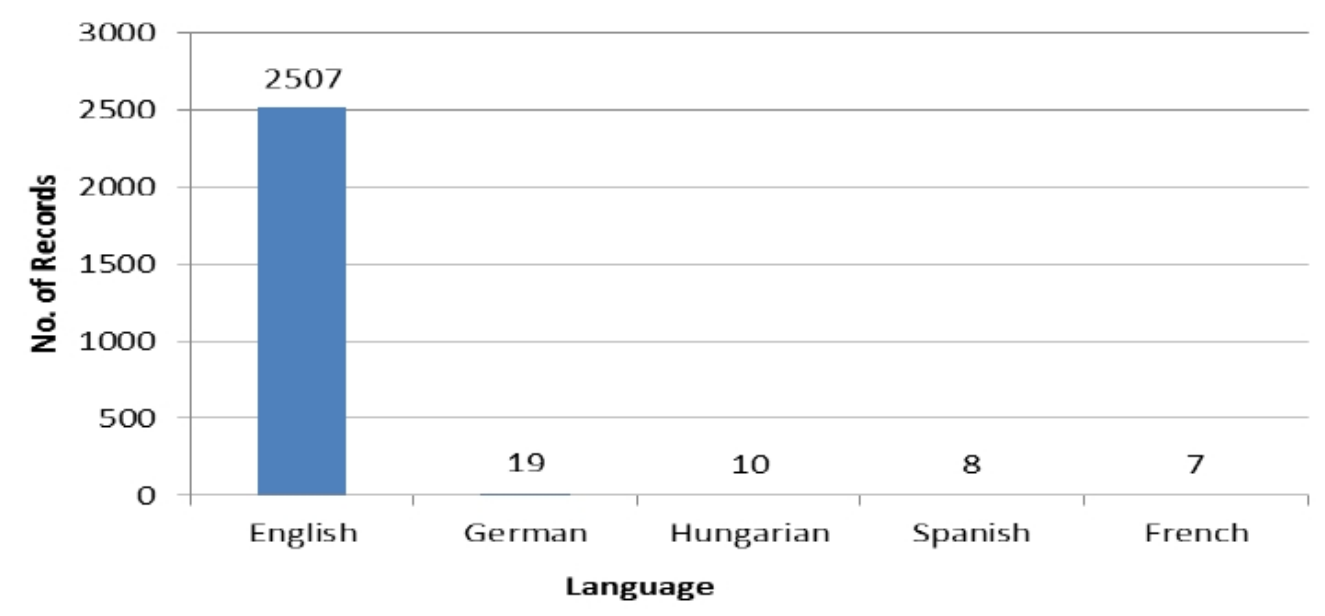

Fig. 6 Language-wise Distribution

Figure 6

Language-wise Distribution 